\title{
Plasmid Modification of Radiation and Chemical-mutagen Sensitivity in Pseudomonas aeruginosa
}

\author{
By P. LEHRBACH, A. H. C. KUNG AND B. T. O. LEE \\ Department of Genetics, University of Melbourne, Parkville, \\ Victoria 3052, Australia \\ AND G. A. JACOBY \\ Massachusetts General Hospital, Boston, Massachusetts $021 \mathrm{I} 4$, U.S.A.
}

(Received 7 June 1976)

\begin{abstract}
SUMMARY
The R factor pMG2 protects Pseudomonas aeruginosa against the lethal effects of ultraviolet (u.v.) and gamma irradiation, and methyl methanesulphonate and $N$-methyl- $N^{\prime}$-nitro- $N$-nitrosoguanidine treatment. Enhanced survival occurs in strains of $u v r^{+} \mathrm{rec}^{+}$(wild-type) genotype and a variety of $u v r e c^{+}$type mutants. No protection occurs in a recA-type mutant. The plasmid also enhances u.v.induced mutagenesis. These effects appear to be due to host-cell controlled plasmid-determined DNA repair function(s). Studies on $P$. aeruginosa strains deficient in DNA polymerase I (polA) suggest that a plasmid-determined repair resynthesis function may be responsible for increased u.v.-survival and enhanced u.v.-mutability in pMG2-containing bacteria.
\end{abstract}

\section{INTRODUCTION}

Certain plasmids such as some colicin factors (Howarth, 1965, 1966), several enteric R factors (Drabble \& Stocker, 1968; Marsh \& Smith, 1969; Siccardi, 1969; MacPhee 1972, 1973 b) and particular Pseudomonas aeruginosa sex factors (Krishnapillai, 1975) confer protection against the lethal effects of ultraviolet radiation on their hosts while increasing the susceptibility of the host to the mutagenic effects of ultraviolet (u.v.) light. Many u.v.-protecting plasmids (MacPhee, I972; Krishnapillai, 1975) also improve cell survival following treatment with a number of agents capable of inducing single strand breaks in DNA (ionizing radiation, alkylating agents and thymine deprivation).

From these studies it has been suggested that u.v.-protecting plasmids may carry a gene or genes which act to increase the extent of repair of host DNA damaged by u.v. radiation, gamma $(\gamma)$ radiation or methyl methanesulphonate. Further, since an intact chromosomal rec $A^{+}$gene is essential for the enteric $\mathrm{R}$ factor, R-Utrecht, to exert its effect on the u.v. response of cells, the plasmid gene product(s) may participate in an error-prone repair pathway (MacPhee, I973a,b).

The $P$. aeruginosa $\mathrm{R}$ factor $\mathrm{pMG}_{2}$ (Jacoby, 1974) confers resistance to gentamicin, streptomycin and sulphonamides and is a member of the compatibility group P-2. This plasmid is transmissible to various strains of Pseudomonas but not to Escherichia coli or other enteric bacteria. Other biological properties of the plasmid include resistance to inorganic and organic mercury compounds, resistance to certain DNA phages and the ability to protect bacteria against the lethal effects of u.v. radiation. 
Table I. Bacterial strains

\begin{tabular}{|c|c|c|}
\hline Strain no. & Strain characteristics* & Reference \\
\hline PAOI & prototrophic, $\operatorname{chl}-2$ & Holloway (I955) \\
\hline $\mathrm{PAO} 287$ & his-52 met-28 ilv-19 arg-I & Stanisich \& Holloway (1969) \\
\hline PU2I(pMG2) & ilvBII2 leu-I str-I rif $\mathrm{FP}^{-}$pMG2 (Gm Sm Su Hg Phi E79) & Jacoby (I974) \\
\hline $\mathrm{PAO} 287(\mathrm{pPLI})$ & his-52 met-28 ilv-I9 arg-I pPLI (Gm Sm Su Hg Phi-E79) & This paper \\
\hline PAO2OOI & arg-32 str-39 chl-2 FP- & $\begin{array}{l}\text { Chandler \& Krishnapillai } \\
\text { (1974) }\end{array}$ \\
\hline PAO2003 & arg-32 str-39 chl-2 rec-2 FP- & $\begin{array}{l}\text { Chandler \& Krishnapillai } \\
\text { (1974) }\end{array}$ \\
\hline TRPFI & $\operatorname{trpFI}$ & $\begin{array}{l}\text { Calhoun, Pierson \& Jensen } \\
\text { (1973) }\end{array}$ \\
\hline GMA 848 & hisII uvr-ro & Kung \& Lee (1973) \\
\hline GMA853 & $u v r-15$ & Kung \& Lee (1973) \\
\hline GMBI 28 & gam-I & Kung \& Lee (I973) \\
\hline GMA856 & hisIII5065 uvr-18 & Kung \& Lee (1973) \\
\hline GMA862 & hisIII5065 uvr-24 & Kung \& Lee (I973) \\
\hline GMBI 17 & $m m s-43$ & Kung \& Lee (1973) \\
\hline GMBI 43 & $m m s-13$ & Kung \& Lee (I973) \\
\hline GMA943 & $t h r-5431$ uvr-107 & Kung \& Lee (1973) \\
\hline GMA878 & his-52 met-28 ilv-I9 arg-I uvr-4I & Kung \& Lee (1973) \\
\hline GMA879 & his-52 met-28 ilv-I9 arg-I uvr-42 & Kung \& Lee (1973) \\
\hline GMA91 8 & $u v r-81$ & Kung \& Lee (I973) \\
\hline GMBI 30 & gam-3 & Kung \& Lee (I973) \\
\hline GMBI IO & $m m s-3$ & Kung \& Lee (I973) \\
\hline GMBI 47 & her-IO & Kung \& Lee (1973) \\
\hline GMBI I I & polAz & Lehrbach et al. (1976) \\
\hline GMBI I 2 & polA3 & Lehrbach et al. (1976) \\
\hline GMBI 23 & polA4 & Lehrbach et al. (1976) \\
\hline
\end{tabular}

* Antibiotic resistances: chl, chloramphenicol; Gm, gentamicin; Sm or str, streptomycin; Su, sulphonamide; rif, rifampin. $\mathrm{Hg}$, resistance to mercuric ion. Phi, interference with phage propagation.

This paper reports a study of the u.v.-protecting ability of pMG2 in a variety of radiationsensitive and chemical-mutagen-sensitive mutants of Pseudomonas aeruginosa (ATCCI5692) (Kung \& Lee, 1973). Several of the mutant strains tested are deficient in a DNA polymerase I type activity (Lehrbach, Kung \& Lee, I976). A recombination-deficient (rec) mutant of $P$. aeruginosa (PAO2003) (Chandler \& Krishnapillai, I974), phenotypically similar to the rec $A$ mutants of $E$. coli $\mathrm{KI} 2$ (Clark \& Margulies, 1965), has also been included in this study.

\section{METHODS}

Bacteria. The standard wild-type strain is $P$. aeruginosa PAOI (ATCCI5692) (Holloway, I955). Strains used in this study are listed in Table I.

Media. Media and the sources of chemicals have been described previously (Kung \& Lee, 1973). Antibiotics were added at the following concentrations $\left(\mu \mathrm{g} \mathrm{ml}^{-1}\right)$ : gentamicin, 20; streptomycin, 200; rifampin, I00. For selecting or scoring $\mathrm{Hg}^{2+}$ resistance, $\mathrm{HgCl}_{2}$ was added to appropriately supplemented minimal medium to a final concentration of $0.5 \mathrm{~mm}$.

General culture procedures and mutagenesis. These techniques have been described previously (Kung \& Lee, 1973).

Conjugational transfer of $R$ factor. Exponentially growing cultures of donor and recipient were mixed in a ratio of $\mathrm{I}: \mathrm{IO}$, respectively, in $3 \mathrm{ml}$ nutrient broth containing $4 \mathrm{mg} \mathrm{KNO}_{3} \mathrm{ml}^{-1}$ (Loutit, Pearce \& Marinus, I968). The mating mixture was incubated overnight without shaking in a sterile glass Petri plate at $37^{\circ} \mathrm{C}$. Recipients harbouring the $\mathrm{R}$ factor were 
selected by appropriate genotype and acquired resistance to gentamicin, streptomycin and $\mathrm{Hg}^{2+}$ ions (sulphonamide resistance was not tested).

$\gamma$ - and $u$.v.-irradiation. This was done as previously described by Kung \& Lee (1973).

Treatment with alkylating agents. Determination of methyl methanesulphonate (MMS) sensitivity has been described previously (Lehrbach et al., 1976). To determine survival in wild-type strains (PAOI and PAO2OOI), the bacteria were suspended in Tris/sodium/magnesium buffer (TNM) containing $0.4 \%(\mathrm{v} / \mathrm{v}) \mathrm{MMS}$. Survival of chemical-mutagen-sensitive , strains was determined in $0.2 \%(\mathrm{v} / \mathrm{v}) \mathrm{MMS} . N$-methyl- $N^{\prime}$-nitro- $N$-nitrosoguanidine (NTG) sensitivity was determined by resuspending $\mathrm{I} \mathrm{ml}$ stationary-phase bacteria in $5 \mathrm{ml}$ TNM containing $20 \mu \mathrm{g} \mathrm{NTG} \mathrm{ml}{ }^{-1}$. The mixture was held at $25{ }^{\circ} \mathrm{C}$ and samples were removed at intervals, diluted and plated on nutrient agar plates.

Host-cell reactivation ( $h$ cr) experiments. Hcr experiments for MMS and u.v. radiation have been described previously (Lehrbach et al., 1976).

U.v.-mutagenesis. To determine the frequency of u.v.-induced mutations, the yield of Trp ${ }^{+}$back mutations of strain TRPF I following various u.v. radiation doses was scored. Samples $(0 . \mathrm{I} \mathrm{ml})$ of irradiated and control suspensions were spread on minimal agar medium supplemented with $2.5 \%(\mathrm{v} / \mathrm{v})$ nutrient broth. Survival following each u.v. radiation dose was determined by plating on nutrient agar.

Assay for DNA polymerase activity. Bacteria to be used in assays were grown on the surface of solid media (nutrient agar) at $37^{\circ} \mathrm{C}$ for $24 \mathrm{~h}$. They were washed from the surface with saline, centrifuged and resuspended in $0 . \mathrm{I} \mathrm{M}$-Tris/0.0I $\mathrm{M}-\mathrm{MgSO}_{4}(\mathrm{pH} 6.6)$ at a concentration of about $10^{11}$ bacteria $\mathrm{ml}^{-1}$. Crude extracts of these suspensions were prepared by sonication in a $150 \mathrm{~W}$ M.S.E. ultrasonic disintegrator and assayed for DNA polymerase activity by the method of De Lucia \& Cairns (1969).

\section{RESULTS}

\section{Effect of $\mathrm{pMG}_{2}$ on radiation sensitivity}

The $\mathrm{R}$ factor $\mathrm{pMG}_{2}$ was transferred to selected members of the defined phenotypic classes of radiation-sensitive and chemical-mutagen-sensitive mutants of Pseudomonas aeruginosa (Kung \& Lee, 1973). The effects of $\mathrm{pMG}_{2}$ on survival following u.v.- and $\gamma$-irradiation are summarized qualitatively in Table 2 .

Typical survival curves for strains with and without the $\mathrm{R}$ factor are given in Fig. I. These studies indicate: (I) pMG2 is capable of enhancing host survival following u.v.- and $\gamma$ irradiation in wild-type and all classes of repair-deficient strains except a recombinationdeficient mutant PAO2003. (2) The protection effect is on the shoulder of the survival curve, the final slope remaining unchanged. This is similar to the effect of Colr (Howarth, I965) and certain enteric $\mathbf{R}$ factors (Siccardi, I969).

\section{Effect of $\mathrm{pMG} 2$ on survival following $M M S$ and NTG treatment}

MMS and NTG are thought to cause single strand breaks in DNA. The repair of single strand breaks, whether due to spontaneous hydrolysis of the methylated base, or to enzymically mediated excision (Lawley, 1974), is effectively identical to the repair of strand breaks caused by ionizing radiation. Table 2 and Fig. $2(a)$ show that the protecting effect of pMG 2 extends to treatment with MMS in phenotypic groups 3 to 7 , I I and wild-type. Qualitatively similar results were obtained for treatment with NTG (Table 2 and Fig. $2 b$ ). 
Table 2. Effect of $\mathrm{pMG} 2$ on survival of repair-deficient strains following u.v.- and $\gamma$-irradiation, and $M M S$ and NTG treatment

\begin{tabular}{|c|c|c|c|c|c|c|c|c|c|c|c|}
\hline \multirow{2}{*}{$\begin{array}{l}\text { Phenotypic } \\
\text { class }\end{array}$} & \multirow{2}{*}{$\begin{array}{c}\text { Strain } \\
\text { no. }\end{array}$} & \multicolumn{4}{|c|}{ Sensitivity to* } & \multicolumn{2}{|c|}{ Hcr ability* } & \multicolumn{4}{|c|}{ Effect of $\mathrm{pMG} 2$ on survival $\dagger$} \\
\hline & & u.v. & $\gamma$ & MMS & NTG & u.v. & MMS & u.v. & $\gamma$ & MMS & NTG \\
\hline wild-type & PAOI & - & - & - & - & - & - & $+t+$ & + & + & + \\
\hline wild-type & PAO200I & - & - & - & - & - & - & +++ & . & + & + \\
\hline I & GMA848 & $\mathbf{s}$ & - & - & - & - & - & $++t$ & . & . & . \\
\hline I & GMA853 & $\mathbf{s}$ & - & - & - & - & - & +++ & . & . & . \\
\hline 2 & GMBI 28 & $\mathrm{~s}$ & $\mathbf{s}$ & - & - & - & - & $++t$ & + & . & . \\
\hline 3 & GMA856 & $\mathrm{s}$ & $\mathrm{s}$ & $\mathbf{s}$ & - & - & - & $+t+$ & +++ & + & . \\
\hline 4 & GMA862 & $\mathrm{s}$ & - & $\mathbf{s}$ & - & - & - & +++ & . & + & . \\
\hline 5 & GMBII7 & $\mathrm{s}$ & - & $\mathrm{s}$ & $\mathrm{s}$ & - & - & + & . & + & + \\
\hline 5 & GMBI43 & $\mathbf{s}$ & - & $\mathbf{s}$ & s & - & - & + & . & + & + \\
\hline 6 & GMA943 & $\mathrm{s}$ & $\mathrm{s}$ & $\mathrm{s}$ & $\mathbf{s}$ & - & - & +++ & + & + & + \\
\hline 7 & GMBI I I & $\mathrm{s}$ & s & $\mathrm{s}$ & $\mathbf{s}$ & $\mathrm{L}$ & $\mathrm{L}$ & +++ & . & + & . \\
\hline 7 & GMBII 2 & $\mathrm{~s}$ & $\mathrm{~s}$ & $\mathbf{s}$ & $\mathrm{s}$ & $\mathrm{L}$ & $\mathbf{L}$ & + & . & + & . \\
\hline 7 & GMBI 23 & $\mathbf{s}$ & $\mathbf{s}$ & $\mathbf{s}$ & s & $\mathbf{L}$ & $\mathrm{L}$ & + & . & . & . \\
\hline 8 & GMA878 & $\mathrm{s}$ & - & $\mathbf{s}$ & - & L & - & $+t+$ & . & . & . \\
\hline 9 & GMA879 & $\mathbf{s}$ & - & - & - & $\mathrm{L}$ & - & $++t$ & . & . & . \\
\hline 9 & GMA9I 8 & $\mathrm{~s}$ & - & - & - & $\mathrm{L}$ & - & +++ & . & . & . \\
\hline Io & GMBI3O & - & $\mathrm{s}$ & - & - & - & - & $++t$ & + & . & . \\
\hline II & GMBIIO & - & - & $\mathbf{s}$ & $\mathbf{s}$ & - & $\mathbf{L}$ & + & . & + & + \\
\hline 12 & GMBI47 & $\mathbf{s}$ & - & $\mathbf{s}$ & $\mathbf{s}$ & $\mathbf{L}$ & $\mathbf{L}$ & $++t$ & . & 0 & 0 \\
\hline Rec & $\mathrm{PAO} 2003$ & s & & & & - & & & . & 0 & \\
\hline
\end{tabular}

* s, sensitive; L, loss of host-cell reactivation ability; -, wild-type response.

$\uparrow$ Survival of plasmid-containing bacteria:,+++ much greater, survival greater than Io-fold; + , slightly increased, less than Io-fold; $o$, similar to bacteria without the plasmid; where no result is shown, the strain was not tested. Degree of protection was determined at a radiation dose (u.v., $\gamma$ ) or time (MMS or NTG) which produced $\mathrm{I} \cdot 0 \%$ survival of bacteria without $\mathrm{pMG} 2$.
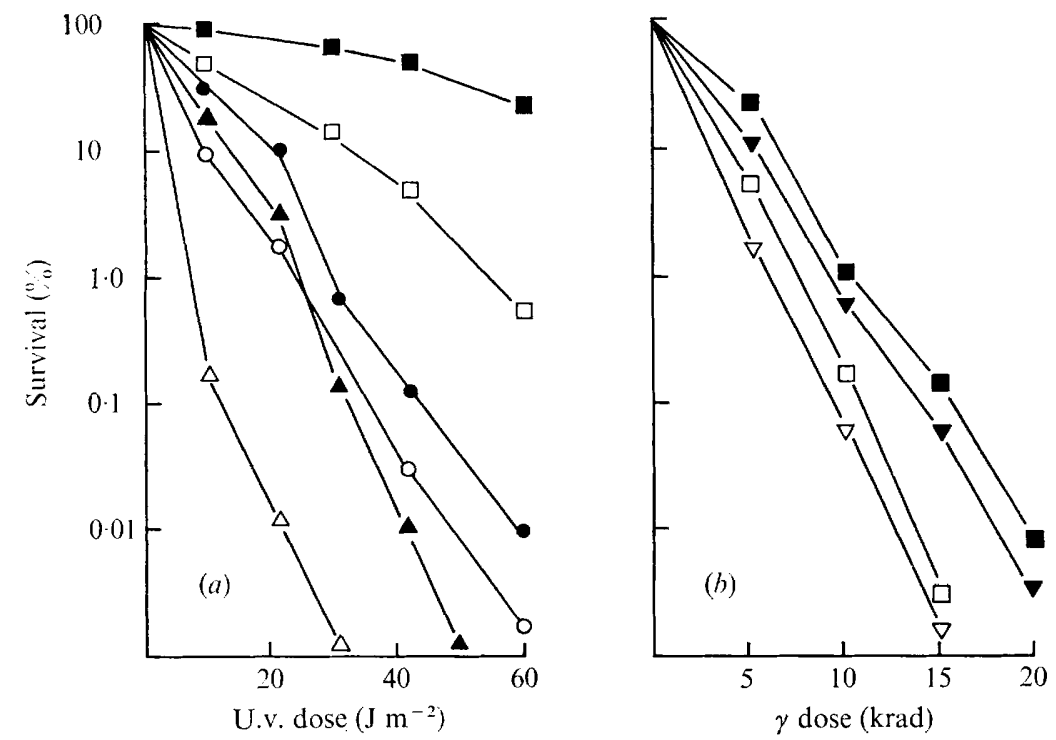

Fig. I. Survival of strains with and without $\mathrm{R}$ factor $\mathrm{pMG} 2$ following: (a) u.v.-irradiation;

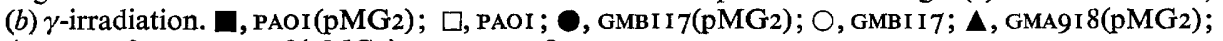
$\triangle$, GMA91 $8 ; \nabla$, GMBI $28\left(\mathrm{pMG}_{2}\right) ; \nabla$, GMBI 28 . 

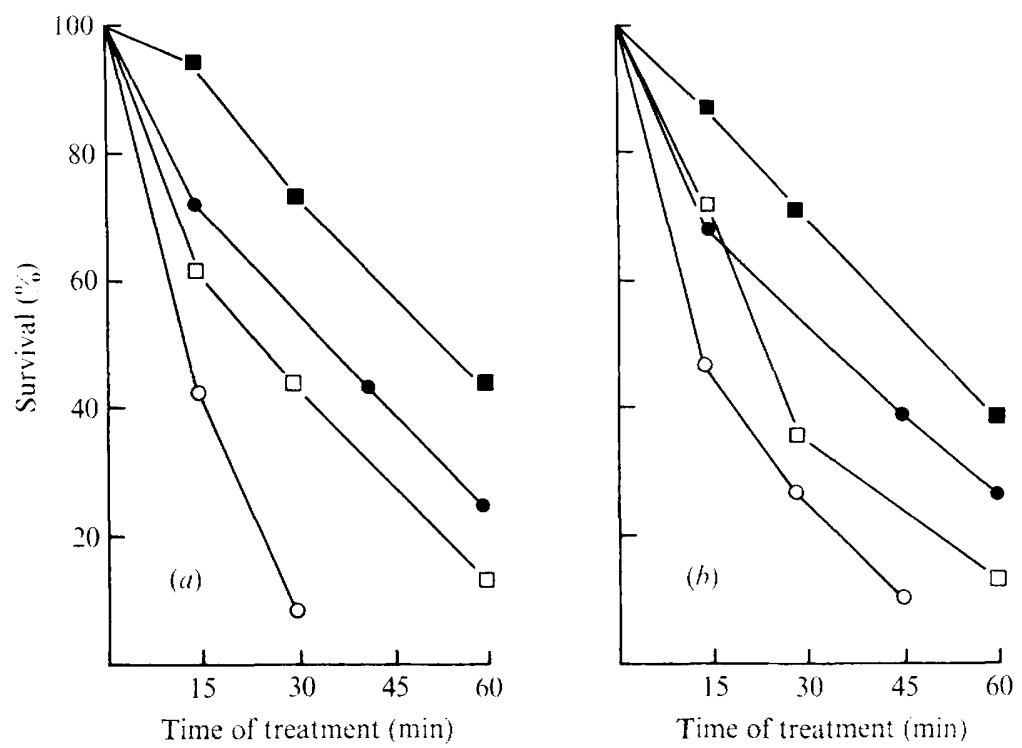

Fig. 2. Survival in strains with and without $\mathrm{R}$ factor $\mathrm{pMG} 2$ following: (a) MMS treatment;

(b) NTG treatment. $\mathbf{\square}$, PAOI (pMG2); $\square$, PAOI ; O, GMBI I 7(pMG2); O, GMBI I 7 .

\section{Influence of $\mathrm{pMG} 2$ in host-cell reactivation (her) mutants}

Protection against u.v. radiation by $\mathrm{pMG} 2$ could conceivably be due to a plasmid function which may participate in the excision of pyrimidine dimers. If so, one might expect pMG2 to (i) restore the u.v.-sensitivity of excision-deficient mutants to nearly wild-type levels, (ii) restore the capacity to host-cell reactivate u.v.-irradiated phage.

Since cells carrying pMG2 fail to plate phage E79 (Jacoby, 1974) it was necessary to isolate a mutant of the $\mathrm{R}$ factor which does not affect the phage plating efficiency of the bacterial host strain. The derived $\mathrm{R}$ factor pPLI is able to transfer the drug-resistance properties and confer protection against u.v. radiation and MMS damage on its host, while cells harbouring pPLI remain sensitive to phage E79.

Both $\mathrm{pMG}_{2}$ and pPLI provide some u.v.-protection to a typical excision-deficient (hcr) strain GMA9I8, although they do not restore this strain to the wild-type level of survival (Fig. I $a$ ) - the result which might have been expected if the protecting effect was due to a plasmid product functionally similar to a u.v.-repair enzyme deficient in an hor mutant.

Wild-type PAOI and strain GMA9I8 were tested for their ability to host-cell reactivate u.v.-irradiated phage E79 in the presence of pPLi, pPLi did not improve the her ability of either strain (Fig. 3).

\section{Effect of rec and pol host mutations on the u.v.-protecting property of $\mathrm{pMG} 2$}

Studies using the enteric plasmid R-Utrecht have shown that the u.v.-protecting effect depends upon a functional $r e c A$ gene present in the host cells (MacPhee, I973 $b$ ). Recently mutants have been isolated in $P$. aeruginosa (Chandler \& Krishnapillai, 1974) which are phenotypically similar to $\operatorname{rec} A$ mutants of $E$. coli. The recombination-deficient rec $A$-type mutant PAO2OO3 carrying pMG2 showed no change in survival following u.v.-irradiation or MMS treatment (Fig. 4). A similar u.v. response has previously been shown by Jacoby (1974) using a u.v.-irradiation hypersensitive rec strain JC90Io. 


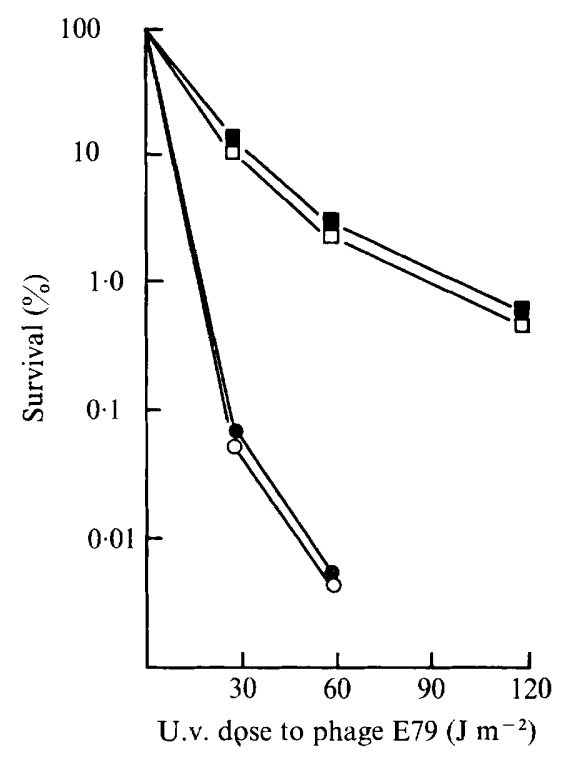

Fig. 3. Host-cell reactivation of u.v.-irradiated phage E79 on strains: $\mathbf{\square}$, PAOI(pPLI); $\square$, PAOI; $\bullet$, GMA9I 8(pPLI); O, GMA9I8.
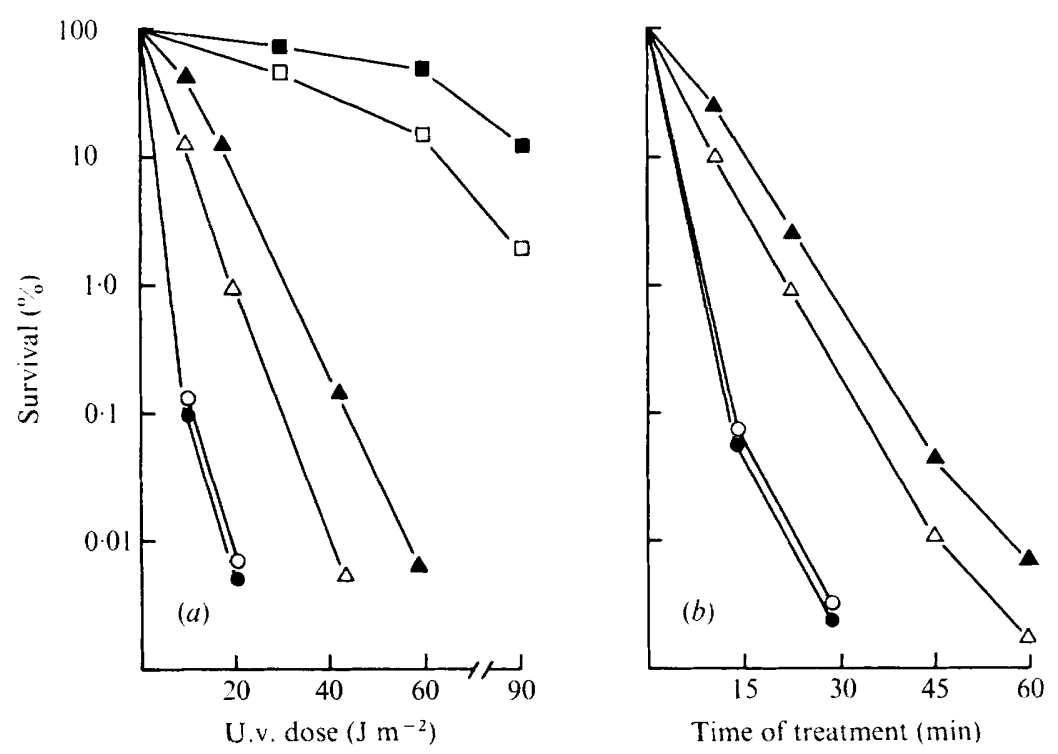

Fig. 4. Survival of $r e c$ and pol strains with and without $\mathrm{pMG}_{2}$ following: (a) u.v.-irradiation; (b) MMS treatment. $\square$, PAO200I(pMG2); $\square$, PAO200I; $\Delta$, GMBII2(pMG2); $\triangle$, GMBII2; PAO2003-(pMG2); O, PAO2003.

The biochemical characterization of several pol mutants of $P$. aeruginosa (Lehrbach et al., 1976) also allows the study of the behaviour of $\mathrm{pMG}_{2}$ in bacteria with a pol background. Strain GMBI I 2 is deficient in the enzyme DNA polymerase I and shows increased sensitivity to u.v. and $\gamma$ radiation, and MMS and NTG as well as having reduced ability to reactivate phage E79 treated with u.v. radiation or MMS. GMBII2 carrying the R factor pMG2 or 

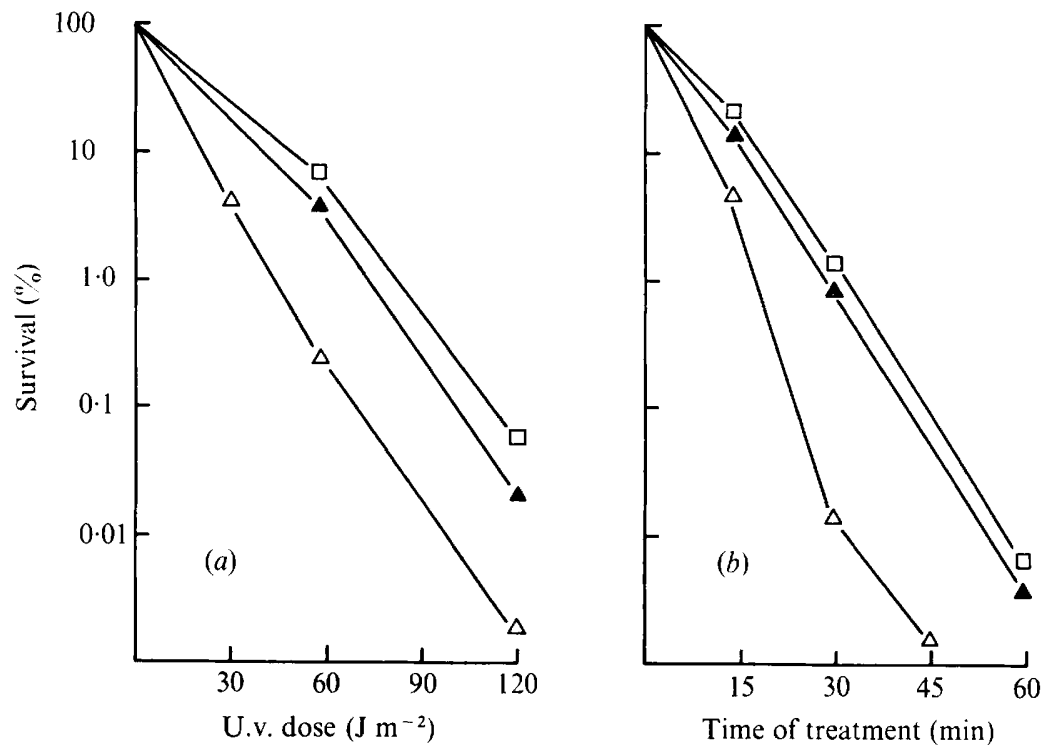

Fig. 5. Host-cell reactivation of (a) u.v.-irradiated, $(b)$ MMS treated phage E79 on strains: $\square$, PAOI; $\Delta$, GMBI I 2 (pPLI); $\triangle$, GMBII 2 .

\section{Table 3. Effect of $\mathrm{pMG} 2$ on u.v.-induction of Trp ${ }^{+}$revertants in strain TRPFI}

Numbers show the frequency of $\operatorname{Trp}^{+}$revertants per $10^{7}$ survivors (corrected for spontaneous frequency); numbers in parentheses show percentage survival.

\begin{tabular}{lcccc} 
Strain & \multicolumn{3}{c}{$\begin{array}{c}\text { Induced frequency at u.v. dose } \\
\left(\mathrm{J} \mathrm{m}^{-2}\right):\end{array}$} \\
TRPFI & $\begin{array}{c}\text { Spontaneous } \\
\text { frequency }\end{array}$ & Io & 20 & 30 \\
& 5 & I0 & 31 & 43 \\
TRPFI(pMG2) & I 8 & 280 & 360 & 560 \\
& & $(100)$ & $(96)$ & $(80)$
\end{tabular}

pPLI was only slightly protected against the lethal effects of u.v.-irradiation and MMStreatment (Fig. 4). Further tests with GMBII2 carrying pPLI showed that this plasmid increases the her capacity of strain GMBI 12 for both u.v.-irradiated and MMS-treated phage E79 to a level approximately equal to that of the wild-type parent strain PAOI (Fig. 5). Plasmid pPLi had no detectable effect on hor capacity in the wild-type parent (Fig. 3).

\section{Influence of $\mathrm{pMG} 2$ on u.v.-induced mutation}

The previous results suggest that $\mathrm{pMG} 2$ provides hosts deficient in the enzyme DNA polymerase I with a plasmid-borne product which can participate in the repair of single strand gaps. Protection by $\mathrm{pMG}_{2}$ depends on a RecA ${ }^{+}$phenotype and since error-prone repair processes depend on an intact $r e c A^{+}$gene (Witkin, 1969) we determined whether pMG2 had an effect on the yields of induced mutations. The $\mathrm{R}$ factor was transferred to the tryptophan auxotroph TRPFI (Calhoun et al., 1973). Back mutation to prototrophy was tested following exposure to low doses of u.v. radiation. pMG2 substantially increased the mutation frequency induced by u.v.-irradiation and also caused a three- to fourfold increase 


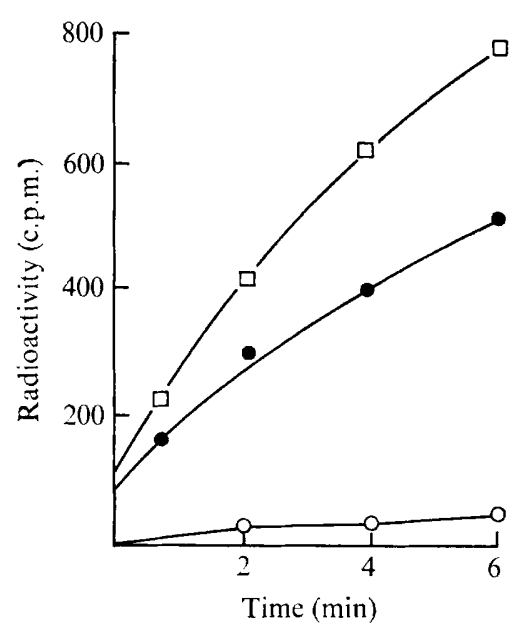

Fig. 6. Assay of polymerase activity of strains: $\square$, PAOI ; ๑, GMBI I2(pMG2); O, GMBI I2.

in spontaneous back mutation (Table 3). Similar results were obtained for the mutant $\mathbf{R}$ factor pPLI.

\section{DNA polymerase activity associated with $\mathrm{pMG} 2$}

Studies with the u.v.-protecting plasmid R-Utrecht (MacPhee, 1974) have presented evidence of a plasmid-borne DNA polymerase function resembling the chromosomal DNA polymerase I (i.e. readily assayable in crude sonicated extracts).

DNA polymerase assays were performed with strain GMBI I2 harbouring pMG2. Crude extracts of GMBII2 showed no detectable polymerizing activity whereas pMG2 derivatives showed a significant increase in polymerase activity (Fig. 6). This activity was about $50 \%$ of that in extracts of wild-type bacteria assayed under similar conditions (see Methods).

\section{DISCUSSION}

The results indicate that the $\mathrm{R}$ factor pMG2 protects $P$. aeruginosa against the lethal effects of u.v. and $\gamma$ radiation, and MMS and NTG. Enhanced survival occurs in strains of $u v r^{+} \mathrm{rec}^{+}$(wild-type) genotype and $u v r \mathrm{rec}^{+}$type mutants (uvr-type mutants; phenotypic groups $I$ to $6,8,9$ and $\mathrm{I} 2$, Table 2), suggesting that the plasmid gene product(s) may contribute to the dark repair of u.v., $\gamma$, MMS and NTG damaged host DNA.

The presence of the plasmid fails to improve the host-cell reactivation capacity of an hcr-type mutant (GMA9I8) or wild-type strain (PAOI), with respect to u.v.-irradiated phage E79. However, pMG2 significantly enhances the ability of strain GMBII2, deficient in a DNA polymerase I type activity, to host-cell reactivate u.v.-irradiated and MMS-treated phage E79. These results suggest that the plasmid gene product(s) is not involved in the excision step of excision repair, but may participate in the repair of single strand gaps produced in phage DNA following excision of u.v.-induced pyrimidine dimers or as a result of MMS-induced damage.

In wild-type cells $\left(\mathrm{poll}^{+}\right)$of $E$. coli, DNA polymerase I is mainly responsible for carrying out repair replication or repair resynthesis involved in excision repair of u.v.-damage (Monk, Peacey \& Gross, 197I). If the plasmid gene product(s) which may be responsible for the enhanced u.v.-survival of wild-type cells of $P$. aeruginosa can perform a repair resynthesis 
similar to the chromosomal-coded polymerase I enzyme then $\mathrm{pMG} 2$ would not be expected to increase the u.v.-survival of $h \mathrm{cr}$ mutants (presumably unable to excise pyrimidine dimers). In the $P$. aeruginosa her mutants reported here there is increased survival following u.v.irradiation (Table 2).

We have attempted to assess the plasmid-determined repair resynthesis activity by means of a crude extract assay system used for detection of DNA polymerase I activity (De Lucia \& Cairns, 1969). Previous results (Lehrbach et al., 1976) indicated that crude extracts of strain GMBII 2 contained little or no detectable DNA polymerase activity (less than $2 \%$ of normal wild-type activity). However, $\mathrm{pMG} 2$ derivatives of GMBII2 showed a significant increase in polymerizing activity.

Since the u.v.-protecting ability of $\mathrm{pMG} 2$ is dependent on an intact rec $A$ type gene product and the plasmid enhances the level of u.v.-induced mutation (detected by back mutation to $\operatorname{trp}^{+}$in strain TRPFI), it is possible that the plasmid-determined repair resynthesis is involved in an error-prone repair pathway. Therefore it may be the involvement of the plasmid gene product in this error-prone repair pathway that accounts for the increased u.v.-survival of $u v r$-type mutants, pol-type mutants and wild-type strains containing the plasmid.

One hypothesis considered is that the plasmid $\mathrm{pMG}_{2}$ specifies a DNA polymerase type product which is able to take part in the repair of u.v., $\gamma$, MMS and NTG damaged DNA and is more prone to introduce errors during the filling of DNA strand gaps (i.e. certain gaps produced during post-replicative repair and certain excision gaps). Such a function would account for the increased hcr capacity in a polymerase-defective strain and both the u.v.-protection and enhanced u.v.-mutability of cells harbouring pMG2. The possibility of such an enzyme as an inducible function in u.v.-mutagenesis in E. coli has been suggested (Witkin, 1974). Alternatively several plasmid genes may be involved in producing the u.v.-protecting effect and enhanced mutability.

$\mathbf{R}$ factor mutants have been isolated which have lost the ability to enhance u.v.-mutability. Preliminary data show that these mutants have also lost the ability to protect cells against the lethal effects of u.v. radiation. Crude extracts of GMBI I 2 containing one of these mutant $\mathbf{R}$ factors showed no detectable increase in polymerizing activity over that of polymerase-defective strain GMBII2 (unpublished data).

The results therefore suggest that $\mathrm{pMG} 2$ codes for one gene product which participates in an error-prone repair pathway of $P$. aeruginosa. This gene product, detected biochemically by the increased polymerase activity in the polymerase-defective strain GMBII2, is respons. ible for the u.v.-protection and enhanced mutability observed in plasmid-containing bacteria.

This work was supported by a Research and Training grant from the Australian Institute of Nuclear Science and Engineering. We would like to thank Dr F. P. Imray for her comments during the preparation of the manuscript and Margaret Sawyer for her help. G. A. Jacoby was supported by a grant from the National Sciences Foundation. Gentamicin sulphate (Schering) was a gift from Essex Laboratories.

\section{REFERENCES}

Calhoun, D. H., Pierson, D. L. \& Jensen, R. A. (I973). The regulation of tryptophan biosynthesis in Pseudomonas aeruginosa. Molecular and General Genetics 121, I I 7-I 32.

Chandler, P. M. \& KRIShnapillai, V. (I974). Isolation and properties of recombination-deficient mutants of Pseudomonas aeruginosa. Mutation Research 23, I5-23. 
Clark, A. J. \& Margulies, A. D. (1965). Isolation and characterisation of recombination deficient mutants of Escherichia coli KI2. Proceedings of National Academy of Sciences of the United States of America 53, $45 \mathrm{I}-459$.

De LUCIA, P. \& CAIRnS, J. (1969). Isolation of an E. coli strain with a mutation affecting DNA polymerase Nature, London 224, $1164-1 \mathrm{I} 66$.

Drabble, W. T. \& Stocker, B. A. D. (1968). R (transmissible drug resistance) factors in Salmonella typhimurium: pattern of transduction by phage $\mathrm{P}_{22}$ and ultraviolet-protection effect. Journal of General Microbiology 53, 109-1 23.

Holloway, B. W. (1955). Genetic recombination in Pseudomas aeruginosa. Journal of General Microbiology I3, 572-581.

HowarTH, S. (1965). Resistance to the bactericidal effect of ultraviolet radiation conferred on enterobacteria by the colicine factor coll. Journal of General Microbiology 40, 43-55.

HowarTH, S. (I966). Increase in frequency of ultraviolet induced mutation brought about by the colicine factor coll in Salmonella typhimurium. Mutation Research 3, I29-1 34.

$\mathrm{J}_{\mathrm{ACOBY}}$, G. A. (1974). Properties of R plasmids determining gentamicin resistance by acetylation in Pseudomonas aeruginosa. Antimicrobial Agents and Chemotherapy 6, 239-252.

Krishnapillai, V. (1975). Resistance to ultraviolet light and enhanced mutagenesis conferred by Pseudomonas aeruginosa plasmids. Mutation Research 29, 363-372.

KunG, A. H. C. \& LEE, B. T. O. (I973). The isolation and survival characteristics of radiation and chemicalmutagen sensitive mutants of Pseudomonas aeruginosa. Mutation Research 20, 175-190.

LAWLEY, P. D. (1974). 'Excision' of bases from DNA methylated by carcinogens in vivo and its possible significance in mutagenesis and carcinogenesis. In Molecular Mechanisms for the Repair of DNA, pp. 25-28. Edited by P. C. Hanawalt and R. B. Setlow. New York: Plenum Press.

Lehrbach, P., Kung, A. H. C. \& LeE, B. T. O. (1976). Mutants of Pseudomonas aeruginosa deficient in DNA polymerase I. Mutation Research (in the Press).

Loutit, J. S., Pearce, L. E. \& Marinus, M. G. (I968). Investigation of the mating system of Pseudomonas aeruginosa strain I. Kinetic studies. Genetical Research 12, 29-36.

MACPHEE, D. G. (1972). Effect of an R factor on resistance of Salmonella typhimurium to radiation and chemical treatment. Mutation Research r4, 450-453.

MACPHeE, D. G. (1973a). Effects of an R factor and caffeine on ultraviolet mutability in Salmonella typhimurium. Mutation Research. 18, 367-370.

MACPHEE, D. G. (1973 b). Effect of rec mutations on the ultraviolet protecting and mutation enhancing properties of the plasmid R-Utrecht in Salmonella typhimurium. Mutation Research I9, 357-359.

MACPhEe, D. G. (I974). DNA polymerase activity determined by the ultraviolet-protecting plasmid, R-Utrecht. Nature, London 251, 432-434.

MARSH, E. B. \& SMITH, D. H. (I969). R factors improving survival of Escherichia coli K-I 2 after ultraviolet irradiation. Journal of Bacteriology 100, I28-139.

Monk, M., PeAceY, M. \& Gross, J. D. (I97I). Repair of damage induced by ultraviolet light in DNA polymerase-defective Escherichia coli cells. Journal of Molecular Biology 58, 623-630.

SiCCARDI, A. G. (1969). Effect of R factors and other plasmids on ultraviolet susceptibility and host cell reactivation property of Escherichia coli. Journal of Bacteriology 100, 337-346.

Stanisich, V. A. \& Holloway, B. W. (1969). Conjugation in Pseudomonas aeruginosa. Genetics 6r, 327-339.

WITKIN, E. M. (1969). Ultraviolet induced mutation and DNA repair. Annual Review of Microbiology $\mathbf{2 3}$, 487-5I4.

WITKIN, E. M. (I974). Relationships among repair, mutagenesis and survival: overview. In Molecular Mechanisms for the Repair of DNA, pp. 347-353. Edited by P. C. Hanawalt and R. B. Setlow. New York: Plenum Press. 